\title{
VIABILITAS RAGAM HIAS SULUR-GELUNG
}

\author{
Agung Wicaksono dan Akhmad Nizam
}

\begin{abstract}
Motive of ukel, lung or plant tendrils (forming like question mark) spiraling inside and outside is named sulur gelung ornament. These ornaments are often found in Hinduism and Budhist temples even in the mosque with particular style. Sulur gelung ornament has to be fondness for people when we look at the craft as visual art. Many artefacs of heritage often visualized form of lung or ukel. In javanese fashion ukel as trendil of hair fastened by ukel konde. Ukel konde is used for make up on the face also for forming of puppet's hair and isen-isen, even for forming of punokawan's hair (Semar, Gareng, Petruk, and Bagong). Form like ukel is also found in the architecture of mosque especially on the mihrab or altar, we can also be found in the architecture of javanese traditional house. The temples of Hinduism and Budhist in Java have ornament of sulur gelung, for example Candi Gondosuli, Candi Gedongsongo, Candi Kalasan, candi Prambanan, Candi Sewu, Candi Lumbung, and many of temples in East Java.

Is this ornament comes from India through the Hinduism or Hinduism-Budhist diffusion to Java? Or possibly this is an original local archetype of java or is this the result of aculturation of Hinduism-Budhist, Java, and Islam ? This reaserch will review the sulur gelung ornament provenience which is commonly using as fix pattern and the spirit or viability of javanese style. The sulur gelung ornament has evoluted since Hinduism-Budhist until Islamic diffusion as reception religion in the culture.
\end{abstract}

Key wors : aculturation, ornament, sulur-gelung

\section{PENDAHULUAN}

Masyarakat Jawa sejak awal sejarahnya berulang kali dan terus menerus berhadapan dengan berbagai kebudayaan asing. Akibat kontak kebudayaan tersebut, kebudayaan asing telah mempengaruhi kebudayaan Jawa "asli". Tingkat pengaruh ini mendapat perlakuan yang berbedabeda, di satu segi terlihat menonjol sedang di segi lain hampir tidak terasakan. Bahwa kesenian Jawa mendapat pengaruh Hinduis
India sudah jelas diketahui. Kemudian datang pengaruh Islam yang menafikan kepercayaan ratusan tahun sebelumnya.

Warisan seni yang melimpah ini justru merupakan antitesis dalam pandangan Islam. Bagaimana sikap dan tanggapan masyarakat Jawa terhadap kehadiran pengaruh luar, lebih tepatnya bagaimana kreativitas seniman Jawa dalam mengolah tema khususnya ragam hias sulur-gelung dan bagaimana visualisasinya

*) Agung Wicaksono dan Akhmad Nizam, (agung_w@yahoo.com), Staf Pengajar Program studi Kriya Seni, Jurusan Kriya, Fakultas Seni Rupa, Institut Seni Indonesia Yogyakarta. 
merupakan persoalan yang menarik, jika mendapati kenyataan bahwa ragam hias Hinduis ini dihadirkan kembali dalam masa Islam yang berseberangan dalam keimanan. Ragam hias ini tidak hanya diwujudkan atau boleh dikatakan memiliki "daya hidup", memiliki viabilitas atau spirit, kemungkinan untuk hidup (Sugono, 2008: 1608). Viabilitas erat kaitannya dengan semangat, jiwa, gairah hidup, daya hidup, yaitu kemampuan melakukan sesuatu, atau kemampuan bertindak, ikhtiyar, upaya untuk bertahan hidup, suatu vitalitas (Alwi, 2005: 241). Upaya untuk bertahan ini tentunya terkait dengan ide dan nilai-nilai yang menyertainya juga pesona ragam hias sulur-gelung itu sendiri.

Setipis apapun masa Islam (awal) memberi warna dan berbeda dengan gaya seni sebelumnya. Pada kurun waktu tersebut terjadi perkembanganperkembangan baru, terjadi pergumulan dan tawar-menawar antara bentuk-bentuk ekspresi religius yang semula representasional dalam seni Hindu difatwakan ke bentuk seni non representasional dalam seni Islam. Berbagai pengaruh luar ini saling mempengaruhi, saling menginspirasi, bahkan ada kesan resistensi dibalik narasi teks budaya.

Sebelum kedatangan pengaruh kebudayaan Islam di Pulau Jawa, kebudayaan Jawa sudah mendapat pengaruh kebudayaan India selama hampir 1000 tahun dimulai dari Kerajaan Tarumanagara di Jawa Barat (abad V Masehi) sampai Kerajaan Majapahit di Jawa Timur (abad XV Masehi). Selama 1000 tahun telah terjadi proses asimilasi, akulturasi, antara budaya lokal yang dalam hal ini adalah kebudayaan India yang bersifat Hindu, Budha, dan Hindu-Budha. Proses percampuran antara keduanya adalah proses yang dialogis dua arah, yang menempatkan kebudayaan lokal sebagai kebudayaan yang tidak pasif. Selama kurun waktu tersebut kebudayaan Jawa sebagai akibat akulturasi antara kebudayaan prasejarah dengan kebudayaan India akhirnya menjadi kebudayaan Jawa lokal (Haryono, 2009: 1-3).

Tanda-tanda kebudayaan jawa lokal ini muncul setelah terjadi pergeseran kekuasaan dari Jawa Tengah ke Jawa Timur, meskipun bibit-bibit kelokalan Jawa secara samar sudah hadir di candi Jawa Tengah. Menurut SP. Gustami, bangunan candi di Jawa Timur memperlihatkan kemampuan daya kreatif kriyawan dan seniman lokal mempertontonkan karya seni yang orisinal dalam tampilan gaya berdasarkan cita-rasa estetik masyarakat asli Jawa Timur. Kehadiran mitos kuno dan makhluk menakutkan dengan kekuatan magi dalam seting supranatural muncul dalam dinding candi sebagai tanda bertemunya mata rantai (mainstream) yang menghubungkan ribuan tahun masa pra-Hindu. Bahkan, sejak permulaan abad ke-16, ketika "bulan sabit" dan "bintang kejora" dari Islam mulai tampil sebagai kekuatan baru di seluruh Indonesia, pelukisan arca dan relief semakin redup, diganti pelukisan bentuk stilitatif dan deformatif yang ornamentif (Gustami, 2007: 112-113).

Islam menggantikan pengaruh Majapahit ketika kerajaan ini mengalami kemunduran. Dengan kedatangan Islam, kebudayaan lama tidak dilupakan dan hilang begitu saja, tetapi justru terjadi percampuran atau akulturasi antara keduanya. Menurut Timbul Haryono, hal ini 
terjadi karena dua hal. Pertama, ketika masa prasejarah, nenek moyang bangsa Indonesia telah pandai memilih dan memilah unsur-unsur kebudayaan asing untuk disesuaikan dengan kebudayaan lokal. Kondisi seperti itu kemudian tetap terjadi lagi ketika kedatangan pengaruh kebudayaan Islam. Kedua, bahwa persebaran kebudayaan Islam ke Pulau Jawa adalah dengan jalan damai dengan pendekatan budaya (Haryono, 2009: 3).

Sukar merefleksikan dengan media yang lebih baik untuk memahami sejarah kebudayaan Indonesia selain melihat secara langsung peninggalan purbakala dalam bentuk kota-kota tua, kuil atau candi, masjid serta makam kuno. Arsitektur pertama yang ditemukan di Nusantara adalah bangunan sederhana, berupa artefak prasejarah kuburan batu, punden berundak dan menhir. Barulah sekitar masa klasik awal (abad VI-IX M.), ditemui arsitektur bangunan yang megah diantaranya Candi Barabudur dan Candi Lara Jonggrang. Dalam kurun masa tersebut dibangun pula ratusan candi-candi yang lebih kecil, hal ini menunjukkan bahwa pengaruh Hindu-Budha sudah mengakar kuat di masyarakat. Untuk memenuhi unsur estetika, maka ragam hiasnya pun ditampilkan. Relief kinara-kinari, ragam hias gajah, kura-kura, relief kala makara, dan pohon kayangan dipahatkan dengan mengagumkan. Ragam hias flora utamanya teratai dan ornamen geometris serta reliefrelief naratif dan dekoratif memperindah dinding dan tubuh bangunan suci tersebut. Beberapa adegan yang terekam pada relief tersebut menggambarkan juga replika arsitektur, perhiasan, pakaian, instrumen musik, gambaran manusia, binatang dan tumbuh-tumbuhan (Holt, 2000: 32-34). Tidak diragukan lagi bahwa seni rupa khususnya ragam hias, telah berkembang sangat menakjubkan pada masa itu.

Penyebaran dan perkembangan Islam di Jawa membawa perubahan dalam berbagai aspek kehidupan. Pendirian bangunan candi dan petirtaan tidak dilakukan lagi, sebagai gantinya muncul bangunan masjid, surau dan makam. Sementara itu sistem kasta dihapus, arca dewa-dewa dan bentuk-bentuk ornamen zoomorphic yang sudah menjadi kelangenan tidak lagi diperkenankan.

\section{Percabangan Tiada Akhir Ragam Hias Sulur-Gelung}

Ragam hias atau ornamen sering diungkapkan oleh para ahli berasal dari kata ornare (bhs. Latin), yang berarti menghiasi (Mulia, 1950: 1017). Di dalam bahasa Indonesia ornamen diartikan sebagai hiasan; lukisan; perhiasan (Sugono, 2008: 1023). Begitu juga pengertian dekorasi dalam bahasa Indonesia diartikan sebagai hiasan (Sugono, 2008: 334). Dari batasan tersebut kehadiran ornamen menjadi seperti sengaja dibuat hanya untuk kepentingan dekorasi. Pada dasarnya, ornamen, ragam hias, motif atau dekorasi memang dapat diartikan sebagai hiasan. Hiasan adalah sesuatu yang hanya ditambahkan saja di atas permukaan benda, bidang, atau hanya untuk mengisi ruang kosong dengan bentuk-bentuk tertentu. Tetapi ragam hias yang dimaksud disini adalah seni ornamen yang perwujudannya telah menjadi kombinasi antara bentuk, fungsi dan isinya (makna) seperti yang dijelaskan oleh SP. Gustami, wujud ornamen memiliki fungsi menghiasi sesuatu 
objek, sehingga apabila dilekatkan atau diterapkan pada benda lain akan menambah nilai benda yang dikenainya. $\mathrm{Di}$ samping itu di dalam seni ornamen sering ditemukan pula nilai-nilai simbolik atau maksud-maksud tertentu yang ada hubungannya dengan pandangan hidup (filsafat hidup) dari masyarakat penciptanya, sehingga suatu benda yang dikenai seni ornamen itu akan mempunyai arti yang lebih bermakna, disertai harapanharapan yang tertentu pula (Gustami, 2008: 4).

Ragam hias merupakan gubahan bentuk-bentuk yang memiliki makna sakral maupun profan, dibuat dengan cara dipahat, digambar, diukir maupun dicetak. Kehadirannya didorong oleh tuntutan estetik dan spiritual yang difungsikan untuk kepentingan dekorasi. Bentuk ragam hias berupa gambaran tentang manusia, binatang, tumbuhan serta bentuk-bentuk abstrak yang diciptakan secara khusus melalui tahap penyederhanaan (abstraksi), penggayaan (stilisasi) sampai penyimpangan (distorsi).

Stilisasi adalah pengubahan bentuk-bentuk di alam untuk disesuaikan dengan suatu bentuk artistik atau gaya tertentu. Sehubungan dengan 'gaya', ada kalanya stilisasi disebut juga 'penggayaan’. Istilah ini berasal dari bahasa Inggris 'stylization' kata kerjanya dalam bahasa Belanda disebut 'stileren' atau 'styleren'. Pada saat bahasa Belanda menjadi rujukan utama istilah-istilah di Indonesia hal yang sama itu disebut `stilasi` dan kata kerjanya adalah 'menyetilir', sekali lagi ini menggunakan konstruksi bahasa Belanda (Soedarso, 2006: 82). Stilisasi masih berurusan dengan bentuk dasar yang diubah menjadi titik tolaknya, kemudian melahirkan bentuk "baru" yang berkarakter lebih sederhana (abstraksi) dan tidak realistik. Hal ini berbeda dengan deformasi yang sudah tidak lagi menghiraukan bentuk dasar tersebut. Ada istilah yang lebih dekat pengertiannya dengan deformasi, yaitu distorsi. Distorsi lebih mengarah pada penyimpangan bentuk dan kenyataan. Bentuk wayang kulit purwa merupakan distorsi (bukan deformasi) pemutarbalikan bentuk asalnya, manusia, yang wajahnya digambar tampak samping, bahunya tampak depan, dan perutnya kembali tampak samping. Sementara itu bagian 'rician` (rincian) diperhalus dan diperindah disesuaikan dengan patokan-patokan yang ada dalam stilisasi; rambutnya digelung, juntaian dodot kainnya dibuat dengan draperi yang sangat teratur, yang kesemuanya merupakan hasil stilisasi demi pencapaian bentuk yang artistik (Soedarso, 2006: 83). Dalam hal ini juga ditemui istilah yang beda-beda tipis, antara 'distorsi' dan 'stilisasi' betul-betul amat dekat perbedaannya.

Pada dinding candi biasanya terdapat ragam hias tumbuh-tumbuhan, berupa lung-lungan yang bergerak mengikal ke kanan dan ke kiri. Pangkal tumbuhnya dapat bermacam-macam, ada yang tumbuh dari vas berbentuk oval, vas yang berbentuk seperti bonggol, ada pula dari dalam vas indah berukir. Sulur tumbuhtumbuhan yang melingkar bergelunggelung tersebut dinamakan sulur-gelung. Sulur-gelung yang keluar dari dalam guci atau vas dinamakan ragam hias purnaghata.

Purna berarti lengkap, utuh, pulih, sembuh, selesai (Utomo, 2009: 390). 
Sementara itu ghata berarti buli-buli, buyung, kendi. Keterangan selanjutnya dikatakan bahwa ghata dihubungkan dengan air yang berarti pemandian, kolam (Zoetmulder, 2004: 280). Perwujudan ragam hias purnaghata merupakan hasil stilisasi tumbuhan teratai yang menyembul keluar dari dalam guci, jambangan atau vas. Menurut Kempers, ragam hias sulur-gelung yang tumbuh dari jambangan yang dari dalamnya memuntahkan bunga-bunga, sulur-sulur dengan daun yang tumbuh lebat di kanan kirinya disebut sebagai lambang kemujuran dan kebahagiaan (Kempers, 1954: 21).

Ragam hias purnaghata secara tematik berasal dari Hindu, tetapi ragam hias ini dipahatkan juga di candi Budha dengan berbagai variasi bentuk terutama pada pangkal tumbuhnya yang berupa guci. Terdapat guci atau vas yang mulutnya lebar seperti tempayan, ada guci yang pada bagian atasnya lebih besar melekuk dan bawahnya lebih ramping beralaskan seperti pilar, ada guci yang bentuknya bulat lonjong seperti bonggol, terdapat juga guci yang berbentuk bulat beralaskan seperti tikar. Satu hal yang terlihat mencolok adalah bunga teratai. Menurut Sedyawati, ragam hias teratai memang umum dijumpai di dinding candi, baik yang merah (padma), biru (utpala), dan putih (kumuda). Warna itu tidak dinyatakan, dan untuk membedakannya hanya dilihat dari cara menggambarkannya. Teratai merah digambarkan sedang mekar, teratai biru digambarkan sedang kuncup, sedang teratai putih digambarkan setengah mekar (Sedyawati, 1993: 84). Mengenai teratai Sukanadi menjelaskan, di Bali dikenal ragam hias patra Cina. Dari namanya patra Cina berasal dari pengaruh motif hias Cina. Motif ini terdiri atas bentuk bunga teratai mekar dan kuncup, dengan tangkai panjang berjuntai. Ragam hias ini sebagai simbol Kemahakuasaan Tuhan Yang Maha Esa, yang menguasai tiga alam, yaitu bhur, bwah, swah, karena bunga teratai hidup di tiga tempat, akarnya di lumpur, batangnya di air, dan bunganya di udara (Sukanadi, 2010: 72-73).

Vas atau guci yang berbeda-beda bentuknya ini kemudian memunculkan nama Purnakalasa untuk membedakan dengan bentuk guci purnaghata atau secara umum dapat dikatakan Guci Padma, karena yang keluar dari dalam guci adalah sulursuluran bunga teratai. Menurut Herayati, sulur yang dilukiskan keluar dari guci bentuk bulat disebut motif purnakalasa. Motif ini ada yang dikombinasi dengan penggambaran binatang kijang atau menjangan seperti yang terdapat di dinding luar kaki Candi Pendem. Motif lainnya yang serupa adalah motif Purnaghata berupa sulur-sulur yang keluar dari guci, hanya bedanya guci ini tidak bulat seperti purnakalasa tetapi lebih ramping ke bawah (Herayati, 2000: 54). Jadi terdapat tiga istilah untuk menamakan ragam hias ini yaitu, purnakumbha, purnakalasa dan purnaghata.

Kata kumbha berasal dari bahasa sansekreta yang berarti pot, kendi, bejana, pasu (Zoetmulder, 2004: 534). Keterangan lain menjelaskan bahwa kumbha berarti buyung, tempayan (Utomo, 2009: 197). Kata kalasa berarti tikar, tempat, periuk (Utomo, 2009: 148). Zoetmulder menjelaskan bahwa kalasa berasal dari bahasa sansekreta yang berarti tempayan, kendi, guci juga berarti tikar. Kata kinalasan 
berarti melengkapi dengan tikar (Zoetmulder, 2004: 443). Seperti yang sudah dipaparkan di depan bahwa, kata ghata berarti buli-buli, buyung, kendi, dan dihubungkan dengan air yaitu pemandian, kolam (Zoetmulder, 2004: 280). Terdapat penjelasan yang menarik dari Y. Agustirto yang mengartikan bahwa ghata berasal dari bahasa sansekreta yang berarti bersemangat, rajin juga berarti kendi, periuk, tempayan, stoples (Suroyudo, 1998: 29).

Kenyataannya sulur-gelung tidak hanya tumbuh dari dalam guci. Terdapat sulur-gelung yang tumbuh dari bonggol, uniknya bonggol yang semestinya adalah akarnya itu ternyata bentuknya mirip dengan guci yang bulat. Kadang-kadang bentuknya menjadi tidak jelas antara guci dan bonggol. Ada juga sulur-gelung yang tumbuh dari şangkha (siput) bersayap di Candi Sambisari, dan di Candi Banyunibo şangkha yang seharusnya adalah atribut dewa itu ternyata hanya difungsikan sebagai pot tempat tumbuhnya sulurgelung. Bagaimana juga halnya dengan sulur-gelung yang tumbuh dari ketiak orang, tentu saja dari ketiak orang yang gendut perutnya (gambaran ini dapat dilihat di Candi Lumbung dekat Muntilan). Di candi Borobudur yang menjadi pangkal tumbuhnya sulur-gelung bukanlah bonggol biasa melainkan ikan, ular yang melingkar, kura-kura, orang atau bidadari, dua ekor kera, ketam, burung, babi, sapi, jambangan, kerang dan rusa. Kiranya penjelasan prosais seperti di atas memang tidak mermuaskan.

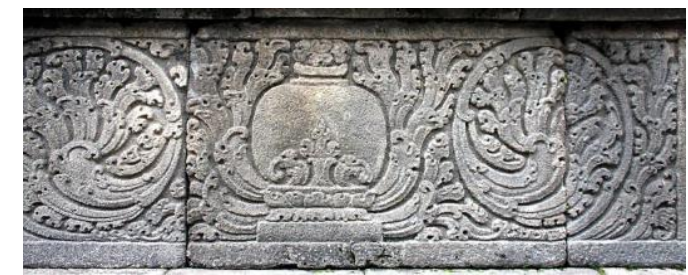

Gambar 1.

Sulur-gelung di kompleks Candi Lara Jonggrang yang terdapat di batur kaki candi Angsa. Sulur-gelung yang dilukiskan keluar dari guci bentuk bulat disebut ragam hias purnakalasa. Zoetmulder menjelaskan bahwa kalasa berasal dari bahasa sansekreta yang berarti tempayan, kendi, guci juga berarti tikar. Kata kinalasan berarti melengkapi dengan tikar. Guci purnakalasa diletakkan di atas padmasana (tempat berdiri atau duduk para dewa) dibawahnya terdapat lapik.

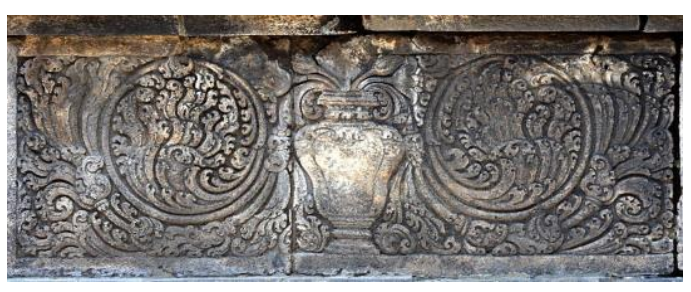

Gambar 2

Ragam hias purnaghata candi Śiwa, guci ini tidak bulat seperti purnakalasa tetapi lebih ramping ke bawah. Sulur-sulur yang bergelung tersebut adalah sulur teratai atau padma, lambang kemujuran dan kebahagiaan. Ghata berarti buli-buli, buyung, kendi, dan dihubungkan dengan air. Kata ghata berarti juga bersemangat, rajin, kendi atau tempayan. Guci yang bermacam-macam ini apapun bentuknya fungsinya adalah sama, yaitu sebagai tempat menyimpan air. Air apakah yang disimpan dalam guci tersebut, tentu saja air suci. Masyarakat Jawa mengenal tĩrtha kamandalu yang berarti kendi tempat 
menyimpan air suci (air penghidupan). Artinya mirip dengan amrtagatha atau guci amrta. Apakah amrtagatha dapat dihubungkan dengan purnaghata yang berfungsi sebagai guci bagi pangkal tumbuhnya sulur-gelung? Air dapat disimpan di dalam guci, sedangkan tumbuhan memang dapat juga tumbuh dari dalam guci atau vas. Guci tersebut selain sebagai tempat tumbuhnya teratai, juga dapat berfungsi untuk menyimpan air suci, lagi-lagi teratai memang dapat tumbuh dari air. Dapat dibayangkan jika air yang dipakai sebagai pangkal tumbuhnya adalah amrtagatha, sehingga wajar kiranya jika ragam hias ini memiliki tempat yang istimewa bagi seniman Jawa.

Sulur yang tumbuh dari dalam guci dipahat dengan teliti, alur batang sulurnya dapat dirunut dengan jelas mulai dari ketika keluar dari guci, lalu sebatang sulur ini tumbuh buku-buku, dari buku-buku inilah keluar cabang sulur yang baru, tumbuh menjadi empat batang sulur. Sulur yang tumbuh dari buku-buku tersebut kemudian bergelung sempurna menjadi satu gelung sulur yang tumbuh lengkap dengan daun dan bunga. Sementara itu dari batang sulur lain yang tumbuh dari buku-buku pertama dapat tumbuh lagi buku-buku yang kedua. Dari buku-buku yang kedua ini dapat tumbuh terus buku-buku yang lain tidak terbatas berapa percabangannya. Percabangan yang terus-menerus tiada batas ini menggambarkan tumbuhnya kehidupan baru dari hanya satu cabang sulur, kemudian bergelung-gelung tiada batas menciptakan kehidupan-kehidupan baru yang lainnya, tiada henti. Sehingga wajar jika ragam hias ini dihubungkan dengan kesuburan. Bahkan ada yang berpendapat bahwa dari bentuk gucinya saja, sebenarnya sudah menggambarkan vulva, tentu saja interpretasi aurat ini perlu tafsiran lebih lanjut.

\section{Kecerdikan Seniman Jawa-Islam}

Bagaimana kebudayaan Jawa ketika bertemu dengan Islam, dapat diamati dari jenis artefak yang kuat ciri Islamnya, yaitu masjid dan makam. Masjid secara etimologi berasal dari kata pokok dalam bahasa Arab, sajada (tempat sujud). Kata ini mendapat awalan ma, sehingga menjadi kata masjid. Dalam lidah orang Indonesia lafal ini diucapkan menjadi "mesjid". Kata masjid tidak selalu menunjukkan sebuah tempat atau gedung khusus ibadah umat Islam. Masjid di dalam konteks sekarang berarti bangunan tempat menjalankan ibadah shalat, meskipun sebenarnya di dalam ajaran Islam menjalankan shalat tidak terikat pada suatu bangunan tertentu.

Bangunan masjid Islam awal Indonesia, memiliki corak arsitektur yang berbeda dengan bentuk masjid Negara lain. Menurut G.F. Pijper tipe masjid Indonesia berasal dari Jawa, sehingga orang dapat menyebut masjid tipe Jawa (1992: 24). Menurut Sofyan, berbagai kenyataan menunjukkan bahwa produk budaya orang Jawa yang beragama Islam mengarah kepada polarisasi Islam kejawaan atau Jawa yang keislaman (Sofyan, 2002: 119). Sebagai suatu cara pendekatan dalam proses akulturasi, kedua jalan ini ditempuh dan menjadi strategi dakwah yang efektif ketika dua kebudayaan saling bertemu. Di dalam proses ini terjadi pencampuran unsur-unsur kedua kebudayaan. Pertama-tama unsurunsurnya dapat dikenali dengan mudah, tetapi lama-kelamaan terjadi pembauran, 
saling meminjam dan saling menginspirasi dan akan muncul sifat-sifat baru yang tidak dijumpai dalam kebudayaan induknya.

Tampaknya tradisi menyelaraskan antara Islam dan budaya Jawa ini telah berlangsung sejak awal perkembangan Islam di Jawa. Proses kebudayaan seperti diuraikan di atas rupanya terjadi berulang kali di Indonesia, khususnya Jawa ketika pembawa agama Islam hadir di pulau ini. Apalagi proses akulturasi ini berhadapan dengan watak orang Jawa yang cenderung bersifat moderat serta mengutamakan keselarasan (Sofyan, 2002: 120). Tidak dipungkiri bahwa selama itu tentu terjadi konflik dan ketegangan-ketegangan. Pemakaian ragam hias teratai, kala mata satu, singa dan mungkin pohon hayat dalam bentuk lanskap gunung menunjukkan betapa dominannya simbol-simbol praIslam dalam seni Islam. Menghadirkan kembali simbol-simbol lama tersebut menurut beberapa ahli digunakan sebagai wahana tutur yang efektif disamping memang berfungsi sebagai hiasan. Kemahiran seni pahat ini diwarisi dari tradisi seni pahat candi yang memiliki khazanah perbendaharaan ragam hias yang melimpah. Kontinuitas adaptasi simbolsimbol dari kekayaan bentuk ragam hias masa sebelumnya dimodifikasi untuk mewujudkan gagasan ekspresi religius (Islam).

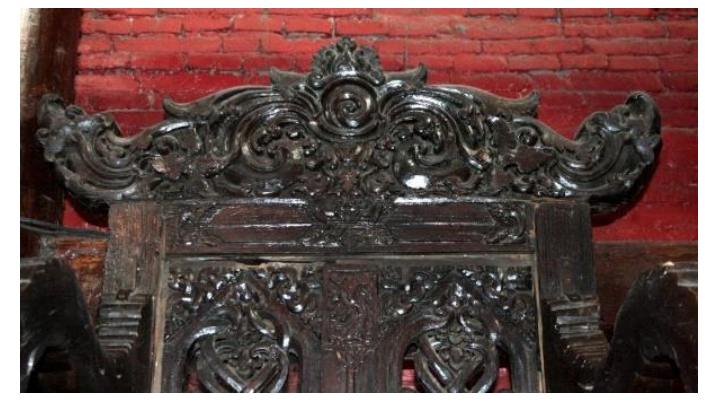

Gambar 3

Mimbar Masjid Agung Cirebon, diberi nama Sang Renggakosa (Atmodjo, 1999: 102). Bentuknya seperti kursi berukuran 122 × 66 × $230 \mathrm{~cm}$. memiliki tiga anak tangga dan tangan kursi menyatu dengan tiang mimbar. Ragam hiasnya adalah sulur-suluran bunga teratai, motif rantai, meander dan bingkai cermin.

Masjid Agung Cirebon didirikan pada tahun 1498 M oleh Walisanga atas prakarsa Sunan Gunung Jati. Pembangunannya dipimpin langsung oleh Sunan Kalijaga yang memboyong seorang arsitek bernama Raden Sepat ( seorang arsitek Majapahit) dengan membawa 200 orang pembantunya dari Demak (Atmodjo, 1999: 104). Masjid ini dikenal juga dengan nama Sang Cipta Rasa karena terlahir dari rasa dan kepercayaan.

Artefak yang paling menarik dari segi ragam hias, selain mihrab adalah mimbar lama yang sekarang sudah tidak digunakan lagi. Tidak terlalu sulit kiranya untuk mengaitkan bentuk kala-makara yang dipahatkan pada mahkota mimbar depan dan belakang. Pada mahkota mimbar depan, bagi mata yang terlatih dapat langsung mengaitkan bentuk kala yang ada di atas adalah penggabungan kepala kala dengan unsur cahaya, sinar atau halo. Dengan demikian kaki mimbar yang seharusnya dan "memang" berbentuk 
makara. Tetapi makara yang terdapat pada kaki mimbar dibuat dengan jalinan sulurgelung. Sulur-gelung ini dibuat dengan menggubah jalinan sulur teratai yang berbentuk singa. Stilisasi makara dengan bentuk seperti ini dapat dijumpai juga pada mimbar masjid Sendang Duwur yang lebih abstrak. Meskipun mimbar masjid Sendang Duwur tidak sama identik dengan mimbar Masjid Agung Cirebon, tetapi dapat dikatakan mirip.

Jika mahkota mimbar bagian depan kurang jelas menggambarkan kala-makara, maka pada mahkota mimbar belakang diulang lagi agak jelas dan unik, karena mampu menggambarkan dan meramu ragam hias purnaghata-kala-makara. Bentuk seperti ini (tanpa guci purnaghata) sudah sering diperagaan di candi Kalasan, Sewu dan Lara Jonggrang yang diulangulang dalam panel hiasnya sebanyak ratusan kali, tentu saja dengan bentuk kala yang tidak bermata satu. Keistimewaan komposisi ragam hias ini adalah salah satu contoh kecerdikan seniman Jawa dalam menghadirkan guci purnaghata tanpa mengurangi keindahan dari sulur-gelung yang keluar dari guci, lalu membentuk kepala kala bermata satu. Dari kala ini lalu mengembang ke kanan-kiri membentuk makara yang mengarah ke luar seolah-olah membentang (seperti sayap) karena arah hadap makaranya tidak ke dalam.

Sementara itu bentuk gucinya dapat hadir secara imajiner, yang terbentuk dari pertemuan dua buah 'bingkai cermin' yang sengaja letaknya berhadap-hadapan secara simetris horizontal. Dua buah bingkai cermin ini secara sengaja memberi ruang hadirnya guci yang tepat berada ditengahtengahnya. Dengan demikian guci dapat hadir secara 'tidak sengaja' yang 'disengaja'. Fragmen ragam hias ini terlalu menarik untuk dilewatkan. Meskipun dapat diidentifikasi bahwa mahkota mimbarnya adalah kala mata satu, lengan yang bersayap adalah makara, dan sulurgelungnya tumbuh dari guci purnaghata, tetapi apakah hanya ini yang dimaksudkan? Yaitu hanya merangkai saja warisan Hinduis yang disamarkan dalam jalinan stilisasi? Seniman Jawa ini tentu saja tidak sedangkal itu konsep berkeseniannya, mengingat mereka bekerja langsung dibawah pengawasan seorang wali 'Sunan Kalijaga' atas pesanan sang pandhita ratu, Sunan Gunung Jati sendiri.

Seniman Jawa ini menghadirkan konsep hubungan vertikal "khablumminallah" hubungan antara Tuhan dan hambanya. Kala adalah simbol dunia atas, matahari, sinar dan cahaya, sedangkan makara adalah simbol dunia bawah, bumi, air, ular dan teratai. Lotus adalah simbol kehidupan, hutan dan gunung, sedangkan kepala kala adalah makhluk raja hutan. Kala mata satu seperti halnya praba atau halo sudah sering diperagakan dalam tradisi Hindu untuk menggambarkan tokoh dewa yang suci. Dalam hal ini sinar atau halo tersebut menghiasi kepala kala, meskipun gigi dan taringnya tidak digambarkan. Pola kala mata satu ini dapat ditemukan dengan jelas tergambar di Gapura Bajang Ratu Desa Temon Trowulan Jawa Timur. Sebagai umat Hindu yang 'saleh' mereka tidak mendustakan kebenaran keyakinan mereka yang dulu, juga tidak dengan serta merta menerima Islam tanpa pengetahuan.

Sepenggal mimbar kuno ini tidak hanya memberikan kesan gaya seni Hindu klasik, tetapi juga menunjukkan gagasan 
seniman Jawa mewujudkan konsep langit dan bumi menurut rasa Hindu. Dengan kata lain bentuk mimbar dan ornamentasinya tidak diperkenalkan oleh Muslim asing, tetapi oleh orang Indonesia sendiri yang faham dan mengerti benar tradisi seni dan konsep Hindu-Jawa. Tidak mungkin orang Arab itu datang sendiri dan mengukir tembok masjid dan makam. Orang Arab datang berdagang dan mengambil wanita lokal untuk diperistri, sebagai salah satu bentuk strategi dagang dan menyebarkan Islam. Sampai disini akan memancing sebuah pertanyaan yang mustahil untuk dijawab. Apakah sikap beragama seperti ini dibenarkan dalam Islam?

Penyebaran Islam di Jawa menggunakan dua pendekatan, pertama disebut Islamisasi kultur Jawa. Metode pendekatan ini menekankan agar budaya Jawa diupayakan tampak Islam, baik secara formal maupun substansial. Pendekatan kedua dinamakan Jawanisasi Islam, sebagai upaya penginternalisasian nilai-nilai Islam melalui cara penyusupan ke dalam budaya Jawa. Persoalan yang muncul dan sering menjadi bahan perbincangan adalah makna yang terkandung dari pencampuran kedua budaya tersebut. Sebagian pengamat menilai bahwa pencampuran itu hanya sebatas kulitnya saja, sedangkan nilai esensialnya adalah tetap budaya Jawa. Pengamat yang lain justru melihat sebaliknya, bahwa nilai Islam telah menjadi ruh dari penampakan budaya Jawa, meskipun tidak berlabel Islam. Akulturasi atau bahkan sinkretisasi Islam dengan kebudayaan Jawa telah melahirkan konsep kepercayaan serta upacara-upacara ritual.

Heddy Shri Ahimsa Putra justru mengatakan bahwa tingkat pencampuran tidak cukup hanya dimasukkan dalam wilayah akulturasi, tetapi sudah menjadi sinkretis. Heddy mengemukakan, bahwa akulturasi agama Islam di Jawa sebaiknya dilihat dari perspektif budaya, artinya dari perspektif sistem ide atau pengetahuan. Akulturasi dilihat sebagai suatu proses yang berjalan pada tingkat kognitif, bukan pada tingkat perilaku ataupun hasil perilaku. Baik perilaku maupun hasilnya pada dasarnya juga merupakan hasil dari proses pemikiran atau pengetahuan. Proses akulturasi dan hasilnya dapat dipahami dengan baik jika proses akulturasi diletakkan pada tingkat pemikiran, dan hasil dari proses akulturasi pada tingkat ini adalah suatu sinkretisme. Dengan kata lain, proses akulturasi pada tingkat pemikiran, ideologis, tidak lain adalah sebuah proses sinkretisasi (Putra, 1995: 1).

\section{PENUTUP}

Dari sudut bahan dan teknik, memang ada perbedaan gaya atau karakter dari masa klasik awal di Jawa Tengah dengan masa klasik akhir di Jawa Timur, juga memang diakui ada karakter khusus masa Islam. Meskipun ada perbedaanperbedaan bentuk yang menjadi ruh penciptaan ragam hias, tetapi belum ditemukan suatu penemuan teknik baru yang mempunyai daya kejut luar biasa. Dapat dikatakan dari era pra-Islam sampai Islam teknik pembentukannya sama saja, yaitu dengan pahat dan ukir. Sedangkan dari sisi bahan capaian artistiknya masih semartabat. Jika di era pra-Islam ragam hias lebih banyak diterapkan pada batu dan bata, ketika memasuki era Islam, ragam hias lebih banyak diterapkan pada media kayu. Capaian artistik dari media kayu ini masih 
sekufu dengan media batu. Bahkan ada kesan media kayu yang seharusnya lebih elastis tersebut diperlakukan sama dengan media batu, terutama terlihat dari ragam hias panel dan relief. Begitu juga karakter bentuk, irama dan komposisinya sebagian besar sama, yaitu meneruskan tradisi "Jawa" masa lalu.

Era Jawa Timur, seperti yang sudah dikatakan oleh para ahli, ada kecenderungan untuk melepaskan diri dari pengaruh masa lalu yaitu dari India. Proses "melupakan" inilah yang menarik, karena justru dilakukan dengan menggabungkan Hindu dan Budha menjadi Hindu-Budha dengan Jawa. Sulur-gelung yang rumit dan indah pada masa klasik awal Jawa Tengah ketika memasuki Jawa Timur direduksi sedemikian rupa sehingga hanya tangkainya saja yang dihadirkan. Tangkai sulur gelung yang dipotong ini bisa jadi karena alasan teknik, yaitu bahan batu bata kurang masif jika dibandingkan dengan media batu. Sehingga batang kecil sulur yang bergelunggelung itu direduksi dengan hanya mengambil pola lengkungan saja tidak bergelung-gelung. Karena bahan bata mudah gempil (retak) maka pahatan dua buah lajur tangkai yang seharusnya terpisah dijadikan satu saja, atau ditumpuk. Tentu saja alasan bahan bata ini tidak sakhih, karena toh masih dijumpai ragam hias sulur-gelung yang menjadi sulur-lengkung pada media batu seperti yang ditemukan di candi Menak Jinggo. Mungkin alasan yang lebih diterima adalah adanya keinginan untuk melupakan masa lalu yaitu pengaruh India yang sudah mengakar selama seribu tahun.

Memasuki Islam, dapat dilihat kecerdikan seniman Jawa ketika mengolah ragam hias sulur-gelung. Meneruskan tradisisi sebelumnya, yaitu seperti memotong sulur-gelung menjadi sulurlengkung dan juga karena adanya keengganan untuk melukiskan berhala (manusia dan binatang) maka simbolsimbol Hinduis tersebut sedapat mungkin dihindari dalam citra visual. Maka beruntung bahwa sulur-gelung adalah tumbuh-tumbuhan menjalar yang menggambarkannya tidak dilarang. Tetapi sulur-gelung adalah ragam hias yang memiliki akar mitologi mitos kosmogoni penciptaan semesta dalam Hindu. Secara bentuk fisik memang tidak diharamkan dalam pandangan Islam tetapi secara 'maknawi' (batin) ragam hias sulur-gelung mengandung paham syrik (menyekutukan Tuhan), suatu dosa yang amat ditakuti dalam Islam. Menghadapi bahaya laten ini maka seniman Jawa (muslim) yang hidup jiwa dan perasaannya mereduksi tampilan sulur-gelung tersebut menjadi hanya sebentuk tumbuhan merambat, tumbuhan menjalar atau diserupakan menjadi pohon yang tumbuh saja. Bagaimanapun juga tradisi Hinduis sudah mbalung sumsum selama seribu tahun. Dalam hal ini terjadi proses 'reduksi' dan 'intensifikasi'. Secara global bentuknya direduksi, tetapi disisi yang lain mendapat penekanan yang melimpah utamanya pada detil-detilnya. Pada dasarnya mereka melakukan abstraksi (mencari esensinya saja), stilisasi (merubah dan menggayakan) sampai yang paling ekstrim yaitu distorsi (penyimpangan bentuk dan kenyataan).

Hidup dan berkembangnya ragam hias sulur-gelung dalam masa Islam menunjukkan bahwa ketika bersentuhan dengan Islam, seniman Jawa senantiasa 
menunjukkan kecerdikannya. Sampai saat ini karya seni rupa yang mereka tinggalkan selalu memancing interpretasi yang multi tafsir. Tampaknya gerak laku seniman Jawa berusaha menghindari konflik nilai, dengan tidak mengambil posisi yang berhadaphadapan dengan Islam standar (baku-kaku) tetapi mencoba ditafsirkan menurut perspektif Jawa. Dengan kata lain, Islam berusaha dipribumikan. Resistensi tampil dalam nada yang subtil, dalam gaya stilisasi, tersamar dan elegan, sama sekali tidak mengesankan "heroisme".

Ragam hias sulur-gelung yang mengandung makna kosmogoni Hinduis ditangan seniman Jawa ragam hias ini menjadi bermakna ganda, sakral jika dilihat substansinya sekaligus profan, karena bentuknya sudah mengalami penyimpangan. Dapat diinterpretasi sekaligus multi interpretasi. Eksistensi ragam hias ini menjadi tidak tepat jika dikatakan sebagai "hasil dari" sinkretisasi atau akulturasi. Tetapi lebih sebagai gambaran pencarian manusia (seniman Jawa) untuk mengenal dan mendekati Tuhannya melalui simbol dan metafora. Atau bisa jadi, dan ini sulit dibuktikan bahwa praktek keagamaan Islam awal di Jawa bisa jadi memiliki akar yurisprudensi Islam asalnya, memang seharusnya Islam seperti inilah yang dikehendaki. Memang klaim kebenaran sulit untuk dibuktikan, apalagi di era sekarang ini dimana 'kebenaran' bisa direkonstruksi oleh berbagai kelompok prosais yang jauh dari pengalaman rasa nikmat indah menikmati pesona karya seni.

Kedatangan Islam di Jawa bukanlah di daerah pagan, melainkan ke dalam masyarakat pluralis yang penuh tradisi Hindu-Budha dan kepercayaan lain yang telah tertanam berabad sebelumnya. Dibidang seni capaian artistiknya mengagumkan. Kenyataan ini memaksa Islam untuk bisa "menyesuaikan" diri dengan tradisi dan kepercayaan Jawa yang sudah ada.

\section{DAFTAR PUSTAKA}

Alwi, Hasan. Kamus Besar Bahasa Indonesia, Edisi Ketiga, Jakarta: Departemen Pendidikan Nasional, Balai Pustaka, 2005.

Atmodjo, Junus Satrio. Masjid Kuno Indonesia, Jakarta: Proyek Pembinaan Peninggalan Sejarah Dan Kepurbakalaan Pusat, 1999.

Gustami, SP. Butir-Butir Mutiara Estetika Timur, Ide Dasar Penciptaan Seni Kriya Indonesia, Yogyakarta: Prasista, 2007.

- Nukilan Seni Ornamen Indonesia, Yogyakarta: Jurusan Kriya Fakultas Seni Rupa Institut Seni Indonesia Yogyakarta dan Arindo Nusa Media, 2008.

Haryono, Timbul. Seni dalam Dimensi Bentuk, Ruang, dan Waktu, Jakarta: Wedatama Widya Sastra, 2009.

Herayati. Nuansa Ragam Hias Pada Wadah dan Peralatan Rumah Tangga seJawa, Katalog Pameran Bersama Museum Negeri Propinsi se-Jawa, Jakarta: Direktorat Permuseuman Dirjen Kebudayaan Depdikbud, 1999/2000.

Holt, Claire. Melacak Jejak Perkembangan Seni di Indonesia, Terj. R.M. 
Soedarsono, Bandung: Masyarakat Seni Pertunjukan Indonesia, 2000.

Kempers, A.J. Bernet. Tjandi Kalasan Dan Sari, disalin oleh R. Soekmono, Djakarta: Dinas Purbakala Republik Indonesia Penerbitan Dan Balai Buku Indonesia, 1954.

Mulia, T.S.G. dan K.A.H. Hidding. Ensiklopedia Indonesia, Bandung: NV. Penerbitan W. Van Houve, Gravenhage, 1950.

Pijper, G.F. Empat Penelitian Tentang Agama Islam di Indonesia 19301950, Terj. Tudjumah, Jakarta: UI Press, 1992.

Putra, Heddy Shri Ahimsa. "Islam Jawa dan Jawa Islam, Sinkretisasi Agama di Jawa," dalam Seminar Sehari Tentang Kharisma Warisan Budaya Islam di Indonesia, "Islam dan Kebudayaan Jawa: Akulturasi, Perubahan dan Perkembangan", Yogyakarta: Balai Kajian sejarah dan Nilai Tradisional Yogyakarta, Bekerjasama dengan Departemen Pendidikan dan Kebudayaan Kantor Wilayah Propinsi DIY, 1995.

Sedyawati, Edi. Sejarah Kebudayaan Jawa, Inventarisasi dan Dokumentasi Sejarah Nasional, Jakarta: Manggala Bhakti, 1993.

Soedarso, Sp. Trilogi Seni, Penciptaan, Eksistensi, Dan Kegunaan Seni, Yogyakarta: Badan Penerbit Instituit Seni Indonesia Yogyakarta, 2006.

Sofyan, H. Ridin. "Interelasi Nilai Jawa dan Islam dalam Aspek Kepercayaan dan Ritual," dalam H.M. Darori
Amin, Islam \& Kebudayaan Jawa, Yogyakarta: Gama Media, 2002.

Sugono, Dendy. Kamus Bahasa Indonesia, Jakarta: Pusat Bahasa Departemen Pendidikan Nasional, 2008.

Sukanadi, I Made. Seni Hias Pura Dalem Jagaraga, Yogyakarta: Arindo Nusa Media bekerja sama dengan Jurusan Kriya Fakultas Seni rupa, 2010.

Suroyudo, Y. Agustirto. Kamus Sanskerta Indonesia Untaian Catursahasra Kosakata, Jakarta: CV. Sagung Seto, 1998.

Utomo, Sutrisno Sastro. Kamus Lengkap Jawa-Indonesia, Penerbit Kanisius, 2009.

Zoetmulder, P.J. dan S.O. Robson. Kamus Jawa Kuna Indonesia, Jakarta: PT Gramedia Pustaka Utama, 2004. 